\title{
Prescribed fire science: the case for a refined research agenda
}

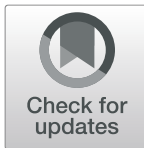

\author{
J. Kevin Hiers ${ }^{1 *}$, Joseph J. O'Brien², J. Morgan Varner ${ }^{1,3}$, Bret W. Butler ${ }^{4}$, Matthew Dickinson ${ }^{5}$, James Furman ${ }^{6}$, \\ Michael Gallagher, David Godwin", Scott L. Goodrick², Sharon M. Hood ${ }^{4}$, Andrew Hudak', Leda N. Kobziar ${ }^{10}$, \\ Rodman Linn ${ }^{11}$, E. Louise Loudermilk², Sarah McCaffrey ${ }^{12}$, Kevin Robertson ${ }^{1}$, Eric M. Rowell ${ }^{1}$, Nicholas Skowronski ${ }^{13}$, \\ Adam C. Watts ${ }^{14}$ and Kara M. Yedinak ${ }^{15}$
}

\begin{abstract}
The realm of wildland fire science encompasses both wild and prescribed fires. Most of the research in the broader field has focused on wildfires, however, despite the prevalence of prescribed fires and demonstrated need for science to guide its application. We argue that prescribed fire science requires a fundamentally different approach to connecting related disciplines of physical, natural, and social sciences. We also posit that research aimed at questions relevant to prescribed fire will improve overall wildland fire science and stimulate the development of useful knowledge about managed wildfires. Because prescribed fires are increasingly promoted and applied for wildfire management and are intentionally ignited to meet policy and land manager objectives, a broader research agenda incorporating the unique features of prescribed fire is needed. We highlight the primary differences between prescribed fire science and wildfire science in the study of fuels, fire behavior, fire weather, fire effects, and fire social science. Wildfires managed for resource benefits ("managed wildfires") offer a bridge for linking these science frameworks. A recognition of the unique science needs related to prescribed fire will be key to addressing the global challenge of managing wildland fire for long-term sustainability of natural resources.
\end{abstract}

Keywords: fire behavior, fire effects, fire weather, fireline interactions, fuels characterization, post-fire tree mortality, prescribed burning, wildland fire research

\section{Resumen}

El ámbito de la ciencia del fuego comprende tanto a los incendios de vegetación no controlados como a las quemas prescriptas. La mayoría de las investigaciones en este amplio campo se han enfocado en los incendios de vegetación, a pesar de la prevalencia de las quemas prescriptas y la probada necesidad de que la ciencia guíe su aplicación. Argüimos que la ciencia de las quemas prescriptas requiere de un enfoque fundamentalmente diferente para conectarse con las disciplinas relacionadas de la ciencias físicas, sociales y naturales. También postulamos que la investigación enfocada a preguntas relevantes para las quemas prescriptas va a mejorar la ciencia de fuegos de vegetación en general y estimular el desarrollo del conocimiento útil sobre el manejo de fuegos de vegetación. Dado que las quemas prescriptas son propuestas y aplicadas de manera incremental para para el manejo de fuegos (Continued on next page)

\footnotetext{
* Correspondence: jkhiers@talltimbers.org

${ }^{1}$ Tall Timbers Research Station, Tallahassee, Florida 32312, USA

Full list of author information is available at the end of the article
}

\section{Springer Open}

(ㅇ The Author(s). 2020 Open Access This article is licensed under a Creative Commons Attribution 4.0 International License, which permits use, sharing, adaptation, distribution and reproduction in any medium or format, as long as you give appropriate credit to the original author(s) and the source, provide a link to the Creative Commons licence, and indicate if changes were made. The images or other third party material in this article are included in the article's Creative Commons licence, unless indicated otherwise in a credit line to the material. If material is not included in the article's Creative Commons licence and your intended use is not permitted by statutory regulation or exceeds the permitted use, you will need to obtain permission directly from the copyright holder. To view a copy of this licence, visit http://creativecommons.org/licenses/by/4.0/. 
(Continued from previous page)

de vegetación, y que son intencionalmente iniciadas para lograr metas y objetivos de manejo de tierras, una agenda más amplia de investigación, incorporando aspectos únicos de las quemas prescriptas, se hace necesaria. Ilustramos las diferencias primarias entre la ciencia de las quemas prescriptas y la de la ciencia de fuegos naturales de vegetación en lo que hace al estudio de los combustibles, el comportamiento del fuego, la meteorología, los efectos del fuego, y las ciencias sociales relacionadas con el fuego. Los incendios manejados para beneficio de los recursos ("fuegos manejados") ofrecen un puente para ligar estos marcos científicos conceptuales. El reconocimiento de las necesidades únicas de la ciencia relacionada con las quemas prescriptas, va a ser clave para direccionar el desafío global de manejar los incendios de vegetación para la sostenibilidad de los recursos naturales a largo plazo.

\section{Introduction}

Wildland fire science is a broad interdisciplinary field of study. Current research in wildland fire science includes study of fuels, fire and smoke behavior, fire history, fire meteorology, ecological and biophysical effects of fires, and socio-political influences (Agee 1993; Whelan 1995; Scott et al. 2013). While fire is generally recognized as a fundamental ecological process responsible for maintaining diverse vegetation communities, the primary research focus in wildland fire science since its inception has been on fire suppression or firefighter safety. This is especially true in the US: Gisborne (1942) stated, "Fire research is intended to serve as directly as possible the fire-control men who must first be successful before any of the other arts or artists of forestry can function with safety."

Wildland fire management strategy in the US and elsewhere has gradually shifted from total suppression of all wildland fire toward recognizing the role of fire as an essential ecological process with potential benefits to natural resources and human health under the right conditions (Stephens and Ruth 2005; McCaw 2013; DOI-DOA 2014). This has led to the development of a conceptual dichotomy: wildfires versus prescribed fires (Kaufmann and Shlisky 2005). In this context, "wildfires" are ignited unintentionally (by lightning or human accident) or maliciously (arson). Prescribed fires represent the alternative, here broadly defined as intentional ignitions ranging from individuals igniting fires with purposeful intent and open containment plans based on natural barriers, to highly organized, complex operations with extensive documentation and precise containment objectives. There are often significant differences between the fire behavior, fire regimes, and environmental conditions that are of most interest in the context of these two types of fires. Prescribed fires are often promoted as a solution to minimize impacts from wildfires and maintain ecosystem resilience and are increasingly a global focus (Fernandes and Botelho 2003; Ryan et al. 2013; Molina-Terrén et al. 2016). Yet, there has been a lack of targeted science to support their broader application. Because prescribed fire scenarios are not generally the same as wildfires, it is not sufficient to assume that wildfire research will address prescribed fire information needs. Here we define the term "prescribed fire science" to include research on intentional ignitions designed for specific resource management objectives, with the expectation that the results of this research agenda could also advance managed wildfires that meet resource objectives.

In comparison to wildfires, prescribed fires across the globe have received relatively little scientific attention given their frequency, extent, and relevance to broader natural resource management goals. For example, a review of recent issues of the journals Fire Ecology (13 years) and International Journal of Wildland Fire (14 years) reveals a comparative lack of research emphasis on prescribed fire. ${ }^{1}$ Wildfire-focused articles appear $50 \%$ more and $300 \%$ more than prescribed fire articles in Fire Ecology and the International Journal of Wildland Fire, respectively. Similarly, a survey of awarded grants from the US Joint Fire Science Program since its inception shows an approximate 3:1 ratio of wildfire- to prescribedfire-focused grant awards. This disparity in research attention is incongruent with the extent of wildfires and prescribed fires in many landscapes. For example, the annual extent of prescribed fire in the US regularly outpaces that of wildfire, with typical average values of circa 4 to 4.5 million ha of prescribed fire (Melvin 2018) versus only 2 to 4 million ha of wildfire (NIFC 2019). Furthermore, in many regions across the globe, human ignitions define fire regimes (Chuvieco et al. 2008), and there is often limited capacity or need for suppression. Equally important is the fact that where wildland fire is highly regulated, prescribed fire managers must bear the responsibility of choosing to start a fire, a decision with potentially weighty career and legal consequences, and thus should be afforded the best available science and technology (Yoder 2008). Moreover, the greater opportunities to engineer fire behavior on

\footnotetext{
${ }^{1}$ This survey by co-authors JM Varner and JK Hiers reviewed every article published in the journal Fire Ecology from its inception to the last issue of 2018. For the International Journal of Wildland Fire, we categorized every article from 2005 to 2018. One of three categories was assigned to each study: based on wildfire, based on prescribed fire, or not relevant to either fire type.
} 
prescribed fire translate to a greater need for sciencebased decisions.

Within the existing wildland fire science framework, there is an implicit assumption that science and tools developed for wildfire application are appropriate for prescribed fire. This assumption is problematic for several reasons (Table 1). Planning horizons differ substantially, in that wildfire demands an urgent response, whereas prescribed fire often affords advanced planning implemented by established-and typically local-institutions or individuals. This difference in the planning horizon influences how wildfire research is applied. Beyond initial suppression efforts, wildfire models are driven mainly by a narrow set of variables, the majority of which encompass spatial scales and time frames relevant to landscape wildfire behavior. The primary research focus on wildfires is predicting rate of spread, ensuring firefighter safety, and capturing progression (perimeter growth) of an uncontained fire (Gomes Da Cruz et al. 2013; Cruz et al. 2015; Yedinak et al. 2018). In contrast, managing a typical prescribed fire requires a detailed understanding of many additional complex and interacting variables to meet management objectives. Most prescribed fires occur on a single day or within a few operational periods-nearly always within a defined boundary-thus challenging the relevance of decision support tools developed for wildfire fire management. For example, prescribed fire's multiple ignitions and resulting fire behavior patterns are poorly encompassed by any contemporary fire behavior or smoke prediction model (Furman 2018). Wildfire science applications are often designed for use by government fire agencies responsible for fire suppression with access to standard equipment, emergency personnel, and organizational resources such as those established by the Incident
Command System and the US National Wildfire Coordinating Group (https://www.nwcg.gov/). In contrast, prescribed fire is often conducted by private landowners who are constrained by resource limitations to manage fire with fundamentally different approaches to control (Melvin 2018). Fire behavior and effects are often drastically different between wildfires and prescribed fires (Boer et al. 2009), with strong implications for ecological effects (Covington and Moore 1994), carbon cycling (Hurteau et al. 2008), and emissions production and transport (Goodrick et al. 2013). Because of these differences, prescribed fire management generates unique research questions about fire behavior phenomenon, fine-scale weather, and manipulation of fire to achieve ecological effects. Ultimately, the tools, research, and experiences that aid wildfire suppression have limited application to effectively guide prescribed fire management.

Here we identify fundamental differences between the current approach to wildland fire science and prescribed fire science needs in the areas of coupled fire-atmospheric feedback modeling, characterization of wildland fuels, fire weather prediction, mechanistic fire effects, and socio-political dimensions. Prescribed fires already offer enormous opportunity for studying wildland fire in an experimental context (Stocks et al. 2004; Ottmar et al. 2016), but pursuing prescribed fire science as a distinct research initiative will allow for knowledge and tools to address prescribed fire management needs (Table 2). While we argue that the needs of wildfire and prescribed fire science applications amount to a difference of kind, not degree, there are areas of managed wildfire that clearly would benefit from the proposed prescribed fire science agenda. While we draw supporting examples from prescribed fires and wildfires from the US, many of these concepts span similar differences

Table 1 Fundamental differences between wildfire and prescribed fire science practice and application

\begin{tabular}{|c|c|c|}
\hline Factor & Wildfire & Prescribed fire \\
\hline Planning horizon & Days to weeks & Weeks to years; multiple years to decades \\
\hline Scale at which research is applied & Hundreds to many thousands of hectares & Sub-meter to $\sim 5000$ ha \\
\hline $\begin{array}{l}\text { Primary motivation for science use } \\
\text { and application }\end{array}$ & $\begin{array}{l}\text { Safety of human life, property, and } \\
\text { natural resource values }\end{array}$ & $\begin{array}{l}\text { Meeting resource objectives without } \\
\text { disrupting human life, property }\end{array}$ \\
\hline Post-fire effects actions and evaluation & $\begin{array}{l}\text { Rehabilitation where needed, immediate, } \\
\text { opportunistically afterwards }\end{array}$ & $\begin{array}{l}\text { Observation, immediate, then following } \\
\text { monitoring plans }\end{array}$ \\
\hline Response to above evaluation & Rehabilitation where needed & $\begin{array}{l}\text { Refinement of prescribed burning plan, adaptive } \\
\text { management, reapplication when appropriate }\end{array}$ \\
\hline Study designs & $\begin{array}{l}\text { Opportunistic, mostly lacking pre-fire data, } \\
\text { non-replicated }\end{array}$ & $\begin{array}{l}\text { Pre-fire and control data often incorporated in } \\
\text { fire effects evaluation, often replicable }\end{array}$ \\
\hline Horizon for experimental research & $\begin{array}{l}\text { Limited: opportunistic, often hindered by logistical } \\
\text { hurdles, lack of access during fire; single event }\end{array}$ & $\begin{array}{l}\text { Integrated: intentional planning for desired fire } \\
\text { behavior and effects; multiple and repeated } \\
\text { events (i.e., potential for replication in time and space) }\end{array}$ \\
\hline $\begin{array}{l}\text { Scientific expertise directly involved } \\
\text { in decision-making }\end{array}$ & $\begin{array}{l}\text { Fire behavior, meteorology, smoke science, } \\
\text { fuels management }\end{array}$ & $\begin{array}{l}\text { Fire behavior, fire ecology, fire history, social } \\
\text { sciences, smoke science, soil and watershed } \\
\text { science, meteorology, fuels management }\end{array}$ \\
\hline
\end{tabular}


Table 2 Research needs in prescribed fire science

\begin{tabular}{ll}
\hline Science topics & Priority questions \\
\hline Fuel characterization & What spatial scale does variation in \\
& Wuel influence fire behavior? \\
& moisture dynamics? \\
Fire effects & How does ignition pattern affect tree \\
& stress and survival? \\
& How do variations in season, intensity, \\
& and frequency affect plant, animal, and \\
& soil community responses? \\
& How does ignition pattern influence \\
& interaction of fire lines? \\
Fire behavior & How can we model manipulation of \\
& fire lines and other backing and \\
& flanking ignition patterns? \\
Fire meteorology and & How well do relevant fuels track \\
climatology & moisture and solar radiation? \\
& How much annual variation is there \\
& in atmospheric conditions that allow \\
prescribed fire? & What are opportunities to expand \\
or modify prescribed burning \\
management
\end{tabular}

between the science needs and approaches for intentional application of fire for natural resource management in wildlands across the globe.

\section{Prescribed versus wildfire fire behavior}

While the fundamental physics of combustion operate across all wildland fire, the relevant interacting scales, phenomena, and feedbacks of fire behavior create unique needs for prescribed fire research applications. Nearly all of the operational models in widespread use among fire management agencies produced for wildfire suppression in North America rely on a suite of assumptions to (1) minimize computation time, and (2) focus on the behavior of a point ignition that becomes an outwardly free-burning fire. Most are empirically-not mechanistically-derived. The Rothermel spread model (Rothermel 1972), which underlies nearly all US wildfire behavior tools (Finney 2004; Andrews 2007), assumes free-burning firelines in order to address the maximum forward spread of wildfires for developing suppression tactics. These models are less useful for predicting prescribed fire behavior involving multiple ignitions and interacting firelines. Canadian and Australian systems for fire behavior predictions are based on empirical observations of rates of spread, but they also cannot account for complex fireline interactions typical of prescribed fire (Sullivan 2009a, 2009b). Because fire-atmosphere interactions are not explicitly represented in Rothermel's spread models or other empirical models of fire spread, fire behavior prediction systems based on these equations and commonly used in prescription development fail to adequately inform prescribed fire decision-making and planning. This creates a false sense of precision for managers, which can have dire consequences regarding prescribed fire outcomes (Hiers et al. 2016).

Required knowledge of fire behavior used in prescribed burning often deviates from wildfires in that (1) prescribed fires are usually planned for a pre-defined burn unit and ecosystem; (2) the presence of multiple interacting firelines is nearly always critical to achieve objectives; and (3) managers continuously manipulate fire behavior through time by altering ignition patterns to achieve specific ecological outcomes and to mitigate changing weather conditions (Wade et al. 1989; Ryan et al. 2013). Prescribed fire ignition patterns inherently result in complex interacting firelines, the behavior of which cannot be predicted using commonly available modeling approaches (Furman 2018). Technological advances in fire ignition devices have also outpaced traditional fire behavior prediction. Aerial ignitions are an example of a widely used but poorly studied prescribed burn ignition technique, further complicated by emerging drone ignition. A traditional wildfire spread calculation approach to developing guidelines for aerial ignition grid patterns fails to capture convective interactions-the main driver of fire behavior resulting from mass ignitions (Fig. 1) or resulting smoke management (Fig. 2). Thus, new, coupled fire-atmospheric modeling tools are needed for scenario testing (Linn et al. 2020) to improve prescribed fire application while transforming manager expertise into a translatable, communicable body of knowledge for future practitioners. Given recognized limitations of wildfire focus on free-burning fires (Yedinak et al. 2018), new approaches are needed to account for complex fireline interactions that are fundamental to meeting prescribed fire objectives. Research is needed to account for fire-induced wind fields that would drive fire spread and spotting. Understanding the role of upwind vegetation induced drag, flow field interactions with firebreaks, and vegetation edge effects on fire behavior is critical for understanding fire behavior, particularly in the prescribed fire environment (Linn et al. 2012).

Prescribed fire planning horizons often allow for more computationally intense modeling tools to understand how ignition manipulations could achieve both ecological objectives and keep fire contained within a predefined area (Furman 2018). The development of tools required to take advantage of longer planning horizons lag behind those of models for wildfire prediction (Sullivan 2009a). Since prescribed fire plans often specify the fire 


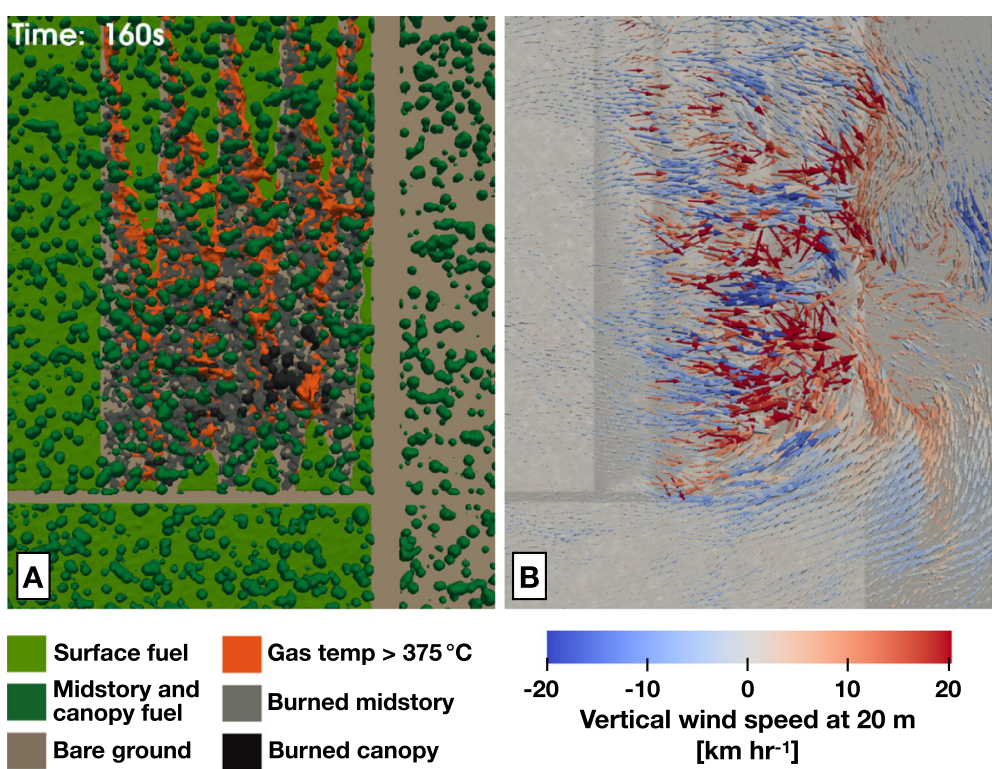

Fig. 1 FIRETEC modeled fuel consumption (A) and within-stand winds (B) in a prescribed burn unit in northern Florida, USA. Note the high spatial variation in fuel consumption (from remnant unburned fuels to patches of crown consumption) and in wind directions and speed

behavior needed to achieve specific resource management objectives relative to ignition patterns, managers have been left without adequate research-based predictive tools to support their decision-making (Wade et al. 1989; Waldrop and Goodrick 2012). Advances in reducing computational time to model these interactions for prescribed fire planning are beginning to show promise for operational prediction (Linn et al. 2020). The benefits of improved complex-ignition fire behavior modeling would therefore include increased alignment of objectives and outcomes, enhanced capacity to predict smoke production and transport, and improved safety.

Wildfire research has begun to couple fire spread models to atmospheric models at a variety of scales (WRF-Fire [Coen et al. 2013], CAWFE [Coen 2013], and FIRETEC [Linn et al. 2002]). These tools are often validated against simplified prescribed fire ignitions that simulate wildfires (Mell et al. 2013). However, even these advanced fire behavior models often focus on free-burning head fires-a condition that rarely occurs over any significant portion of a prescribed burn unit. Understanding and predicting the variation of backing fire (spread into the wind or downslope) and flanking fire (spread perpendicular to the wind) near environmental thresholds of combustion is essential for prescribed fire. Similarly, discontinuous ignition patterns (e.g., dot or dash ignitions that are uniformly spaced fires that spread into each other) are used extensively for moderating fire intensity on prescribed burns. Nonetheless, such techniques that rely on complex fireline interactions lack the science underpinnings given to free-running headfire in modeling or laboratory studies (Linn et al. 2013; Finney et al. 2015).

Concerns also arise when applying fire prediction and fire danger tools such as FARSITE (Finney 1998), NFDRS (Deeming et al. 1972), and BEHAVE+ (Andrews 2007) to discern expected prescribed fire behavior from weather and fuels parameters. Many of these wildfire tools were designed to predict fuel moisture or fire behavior under worst-case scenarios. Most prescribed fire ignition plans call for less extreme weather scenariosso-called "marginal burning conditions"-so that ecological objectives can be met while containment risks are minimized. Tools developed to predict fire behavior in worst-case scenarios may fail to capture fire behavior under typical prescribed fire operation conditions (Zhou et al. 2005). Similarly, the focus of wildfire science on maximum fire intensity and mean fuel consumption, rather than on the range of variation, fails to adequately explain and predict fire effects contained in prescribed fire objectives (O'Brien et al. 2018). Such inaccuracies could result in exaggeration of negative effects of prescribed fire or cancellation of planned prescribed burns when conditions were in fact appropriate for meeting management objectives (Reid et al. 2012).

Wildland fire science has not met the needs of prescribed fire practitioners faced with increasingly complex decisions. Consequently, determination of prescribed fire parameters is generally derived from a manager's experience on how to safely meet objectives. Changing land use patterns, air quality regulations, novel fuels, and climate all come with significant legal ramifications 


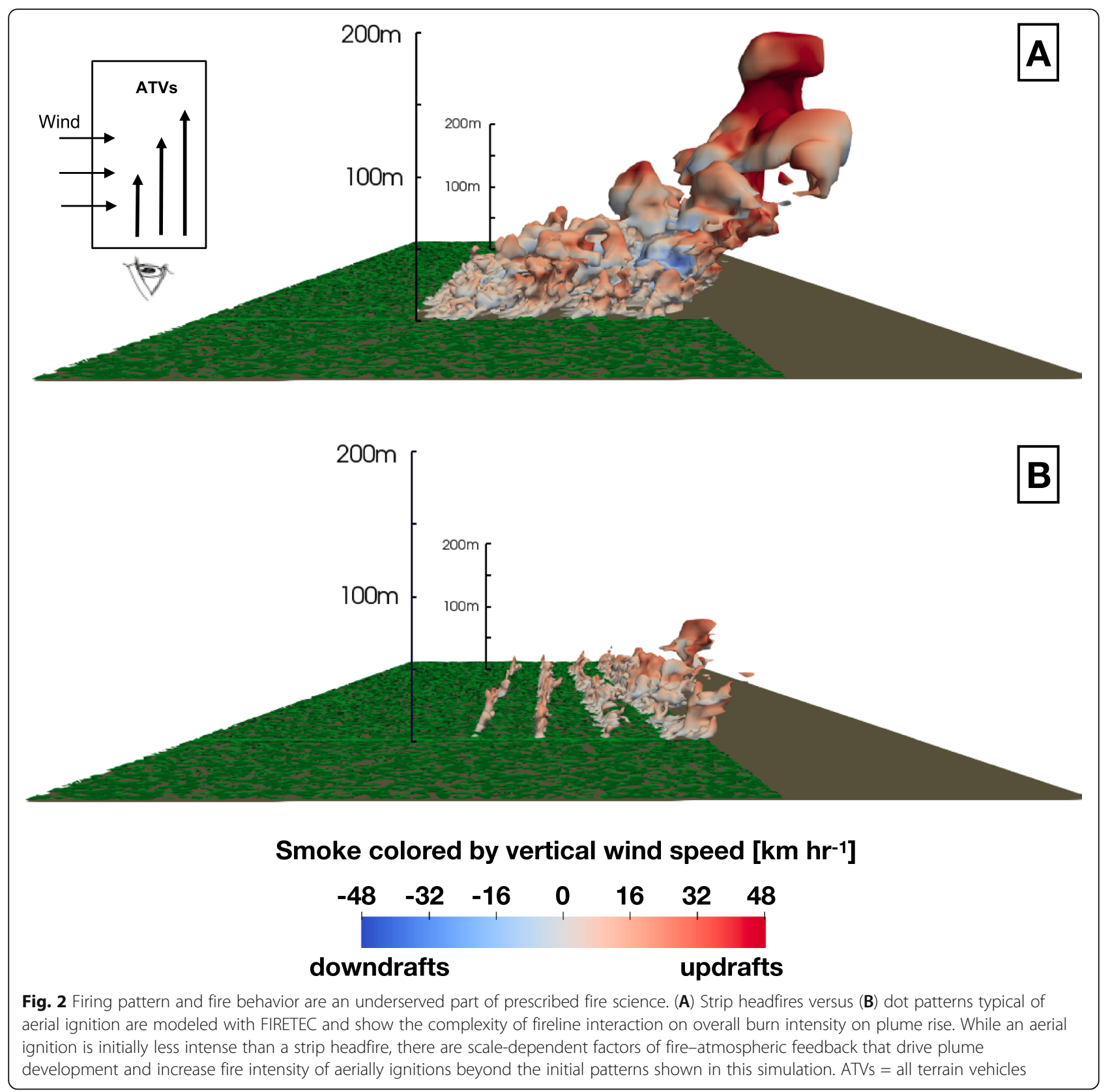

(McCullers 2013). Despite these very real consequences, managers continue to use prescribed fire without the support of a robust research infrastructure. In the absence of mechanistic predictions and models, scenario testing becomes difficult and the education of new prescribed fire managers is inadequate, resulting in the inability to identify possible improvements in prescription parameters and ignition plans as complexity increases. If a prescribed fire results in unintended fire effects, future use of prescribed fire might be discounted as a viable management option even in natural areas where fire is imperative to maintain ecosystem function (e.g., the 2000 Cerro Grande Fire in New Mexico, USA).

\section{Fuels: toward 3- and 4-dimensional} characterization

Adequate multiscale characterization of vegetation structure and fuels is fundamental for predicting prescribed fire behavior and effects (Hiers et al. 2009; Parsons et al. 2017; O'Brien et al. 2018). Stand-level generalizations are a traditional focus of fuels characterizations, and early fuels research was driven by potential fire hazard (Maxwell and Ward 1980) and simplified into fuel models (Anderson 1982) or fuelbeds (Sandberg et al. 2001). These approaches helped to speed predictions of empirical operational fire behavior models (Rothermel 1983). They were subsequently expanded to characterize large landscapes 
potentially subject to wildfire through remote sensing crosswalks (Reeves et al. 2009; Rollins 2009). However, this approach homogenized inherent ecological variations relevant to many prescribed fire outcomes (O'Brien et al. 2018). While valuable in identifying broad characteristics in two dimensions, these approaches overlook finer-scale, three-dimensional (3-D) heterogeneity in fuels that provide context to local fire behavior and effects (Hiers et al. 2009; Achtemeier 2013; Dell et al. 2017). New methods to characterize multiscale mosaics of vegetation are needed to address the diversity of prescribed fire management objectives across ecosystems.

To this end, laser altimetry (e.g., LiDAR) continues to expand the ability to estimate physical fuel properties at higher spatial resolutions and in three dimensions with greater precision than direct field sampling techniques (Loudermilk et al. 2009; Skowronski et al. 2011; Rowell et al. 2016). Yet, how these tools are used to provide input parameters to fire behavior models, such as surface area-to-volume ratios, packing ratios, bulk density, and their spatial heterogeneity must be standardized into sampling and analytical techniques (Hawley et al. 2018).

Already LiDAR data are being used as inputs to models predicting spatially explicit 3-D fire behavior (Parsons et al. 2011). However, monitoring methods continue to rely on coarse-scale, two-dimensional fuel loading estimates (e.g., Brown's planar intercept transects [Brown 1974]) and stand-scale means for characterization of model inputs. Expanding 3-D fuels mapping nationally with standard data collection, analysis, and multi-scale forest characterization is a frontier being pursued by prescribed fire scientists, as evidenced by the Strategic Environmental Research and Development Program (SERDP) funding investment in 3D fuel characterization (https://www.serdp-estcp.org/ News-and-Events/News-Announcements/Program-News/ SERDP-announces-FY-2019-new-start-project-selections). Such improvements in fuels characterization for prescribed fire applications also offer benefits to modeling behavior of managed wildfires to predict ecological effects in structurally complex forest types (Pimont et al. 2009).

Prescribed fire objectives necessitate a detailed and nuanced understanding of the fine-scale micrometeorological (Clements et al. 2016) and phenological conditions (Wiesner et al. 2019) that influence fuel moisture dynamics of both live and dead fuels (Jolly et al. 2014; Kreye et al. 2018). Changes over time represent a "fourth dimension" of fuels characterization. Dynamic within-stand diel patterns of moisture are critical for improving prescribed fire planning and execution. The spatial and temporal variability in fuel moisture modulates local fire behavior (Tanskanen et al. 2006) and influences heterogeneity of burn severity and fire effects, such as the pattern of unburned patches (Hiers et al. 2009; Parsons et al. 2017; Meddens et al. 2018). Fuel moisture predictions as currently generated from remote automated weather stations do not provide adequate estimates in regions where prescribed fire dominates the area burned (Hiers et al. 2019). Prescribed fires are ignited at specified times of day to capitalize on threshold diel fuel moisture dynamics (Banwell et al. 2013; Kreye et al. 2018), but prediction of these fuel moisture thresholds depends on shade and airflow derived from 3-D structural characteristics of the burn unit (Kreye et al. 2018).

Fuel moisture conditions for prescribed fires often include what would be considered marginal conditions for fire spread (Zhou et al. 2005), as managers take advantage of their nuanced, experience-based understanding of fuel moisture and the local weather to safely and efficiently achieve objectives (Fernandes and Botelho 2003). Moisture variation within complex matrices of live and dead fuel particles across both temporal and spatial scales governs fire spread (Nelson 2001; Loudermilk et al. 2018). Similarly, seasonal variation in phenology of living plant material leads to variation in plant flammability (Jolly and Johnson 2018) and rate of particulate matter emitted per biomass consumed (Robertson et al. 2014). Fuel moisture patterns at fine scales further complicate prescribed fire operations in ways not planned for on wildfire operations due to the sequence of ignitions and prescription constraints. For example, prescribed burns are most commonly initiated with a backing fire ignited under conditions frequently closer to the moisture of extinction; however, within-unit variation in moisture can, within hours, produce heterogeneity in fire spread that can challenge containment. In this way, if marginal fire spread under high moisture conditions is delayed, then containment could be challenged when exposed to solar-driven changes in fuel drying rates not predicted by current 1-hour fuel moisture models (Kreye et al. 2018).

Spatial variability in forest stand conditions-even locations of individual trees-strongly influences ignition dynamics and can dramatically alter the effects of a prescribed fire operation. For example, differences in fuel mass, volume, and moisture content of organic lower O-horizon (duff) and peats can alter combustion of smoldering fuels and drive patterns of overstory stem mortality (Varner et al. 2007; Fig. 3) and particulate matter emissions (Robertson et al. 2014). Moreover, the consumption dynamics of coarse woody debris under higher moisture conditions is a research need for prescribed fire planning. Coarse woody debris, often associated with death or damage of individual trees, has long moisture lag times influencing residual smoke associated with longduration smoldering of heavy fuels (Hyde et al. 2011).

\section{Fire effects: questions of scale}

The ecological consequences of fire (i.e., fire effects) further illustrate the distinct needs between traditional 


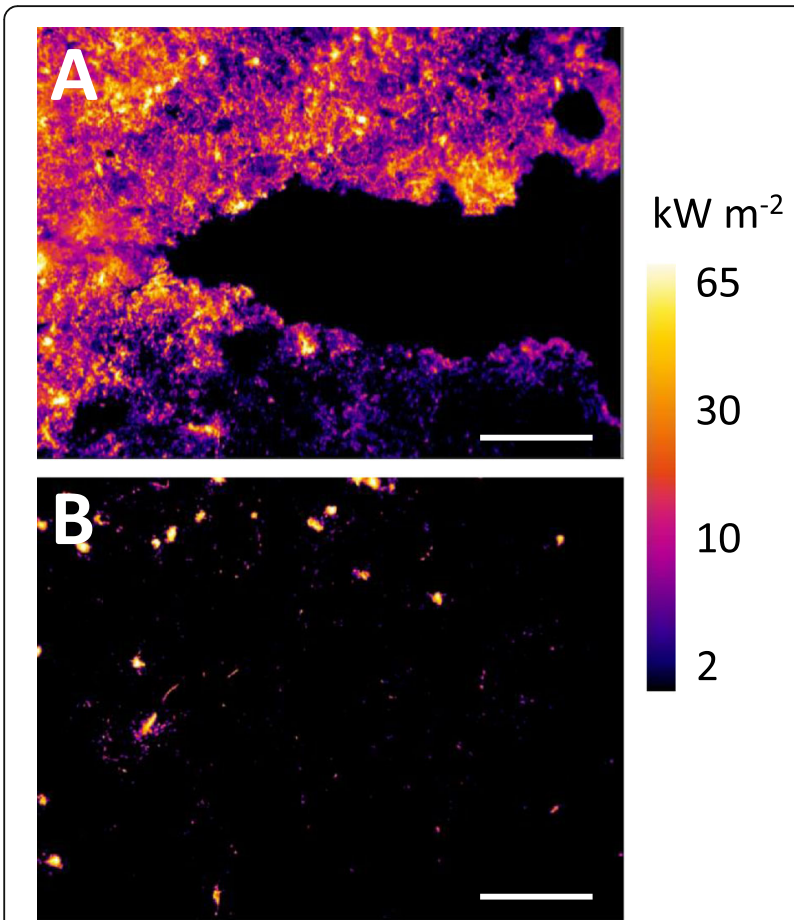

Fig. 3 Fine-scale fuel and fire behavior variation in prescribed burns can have significant consequences for ecological effects. Shown here are two infrared thermographs of a prescribed fire in longleaf pine in northern Florida, USA, on 6 March, 2008. (A) represents the flaming phase and (B) represents patches of residual smoldering consumption of woody fuels. The colors are scaled to radiative power in $\mathrm{kW} \mathrm{m}^{-2}$. The white bar in the lower right corresponds to $1 \mathrm{~m}$. Data are from Eglin Air Force Base, Florida, USA, 14 March 2015

wildfire-centric and prescribed fire research. Prescribed fire is a manipulation of conditions and fire behavior to achieve specific fire effects, which require active consideration before, during, and after a fire (Johnson and Miyanishi 2001). In contrast, wildfire effects are frequently only assessed post fire, and are linked almost exclusively to fire severity rather than directly to fire behavior. Unlike wildfires, prescribed fires are ignited only when acceptable conditions and expected fire behavior align with management objectives for specific fire effects in predetermined locations. In prescribed fire, effects are the goal; in wildfire, effects are to be mitigated, including the impacts of suppression operations.

Ecological consequences are at the core of prescribed fire science since most fires are applied to achieve targeted fire effects. One common ecological objective is to achieve selective mortality or injury to individual species or guilds. For example, in grasslands and many savannas and woodlands, suppression or elimination of encroaching woody vegetation is often the goal (Bragg and Hulbert 1976; Engber and Varner 2012). However, the mechanisms driving selective mortality or injury-and how to control or model a fire to achieve these effects-are poorly understood (O'Brien et al. 2018). For example, manipulating differential fire effects requires an understanding of the type and quantity of energy transfer both within an individual organism and across a stand or landscape (Dickinson and Ryan 2010; Smith et al. 2017; O'Brien et al. 2018). Prescribed fire managers can readily modify the patterns of fire energy release through the timing and pattern of ignition. The effects of these techniques are primarily mediated by fire-atmosphere interactions (specifically patterns of convective energy transfer), fine-scale distribution of fuels and their combustion properties, and the ecological status of organisms being targeted (e.g., phenology or life history stage). Understanding how these mechanisms interact to drive fire effects requires detailed measurements of pre-fire vegetation structure, threedimensional fuel distribution, and patterns of fire energy release during prescribed fire. Measurements taken only after a fire (e.g., post-fire crown scorch or bole char) or at coarse scales (e.g., LANDSAT $30 \mathrm{~m} \times 30 \mathrm{~m}$ pixels) cannot illuminate the mechanisms' driving patterns, reducing their predictive capacity to inform management (O'Brien et al. 2018).

Much of wildfire-derived research focuses on understanding broad landscape patterns of burned versus unburned vegetation. While the "green versus black" dichotomy is important for prescribed fire science, there is a much greater need for understanding variation of energy transfer within burned areas at finer scales (Fig. 4). These scales differ from what is generally investigated in wildfire science, in which studies have focused on landscape patterns of general severity categories (but see Meddens et al. 2018). For example, within-fire variability in both energy release and individual plant mortality has been shown to be an important driver of community assembly and plant population dynamics (O'Brien et al. 2016; Dell et al. 2017). Capturing these mechanisms requires detailed observation of fine-scale fire behavior. Connecting these patterns to stand structure has been described as the ecology of fuels, and this feedback represents a fundamental principle of prescribed fire science (Mitchell et al. 2009).

In the case of wildfire, fire effects typically vary widely and can do so over spatial extents that now frequently exceed 10000 to 100000 ha in the western US (Stephens et al. 2014; Jones et al. 2016). Managing both undesired and desired effects from prescribed fire must be understood and predicted at scales ranging from 1 to 10000 ha. For example, in prescribed fires, tree injury (via damage to crown, bole, or roots) occurs because of differential heat transfer within typically heterogeneous fuels. Directly beneath a tree crown, accumulation of fuel can lead to significant soil heating, which varies significantly from outside of the tree's dripline and affects tree-survival soil processes (Varner et al. 2007). At this scale, determining 


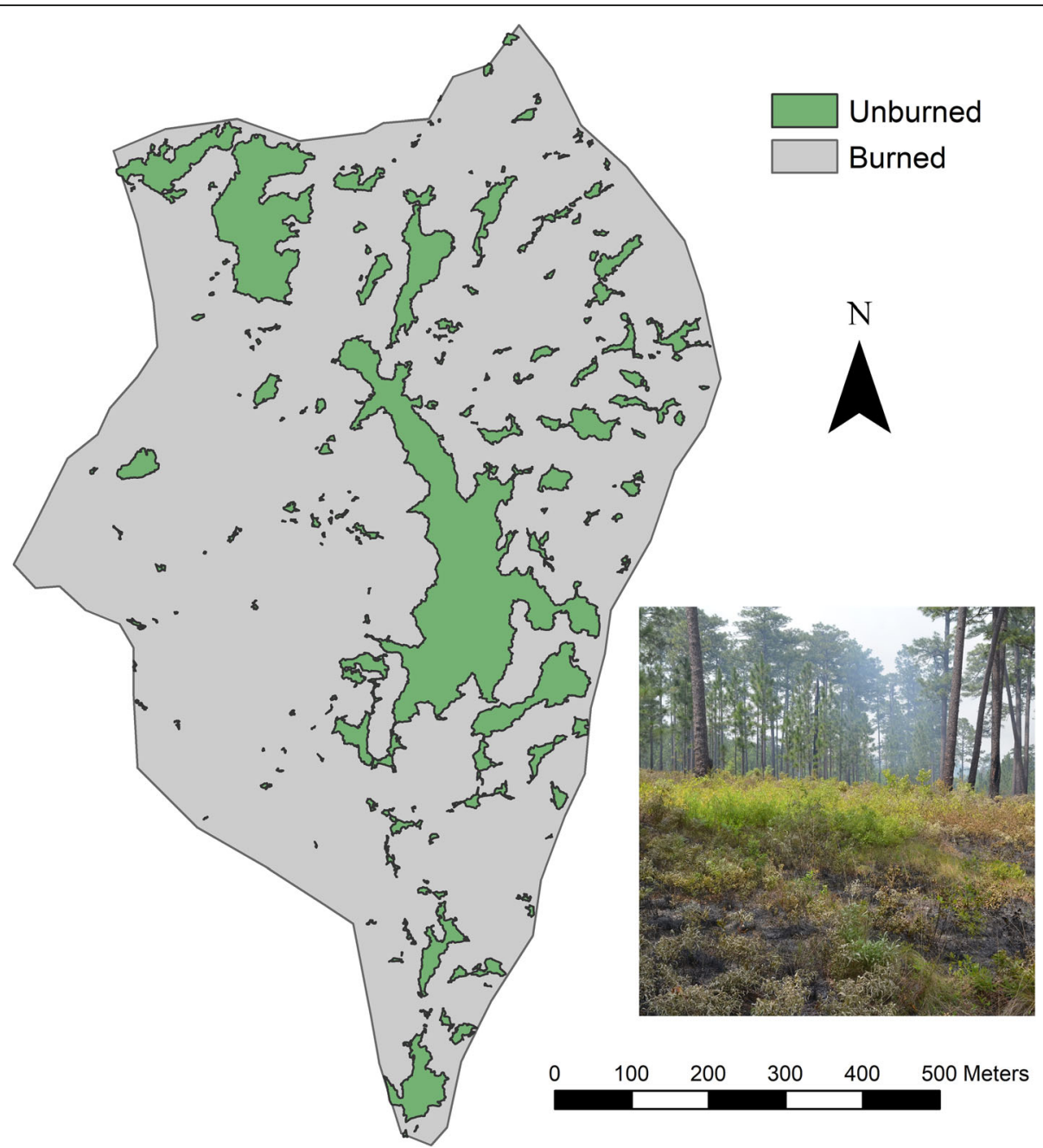

Fig. 4 Map of unburned patches in a heterogeneous prescribed fire of native longleaf pine-wiregrass vegetation in southern Georgia (Arcadia Plantation), USA. Post-burn patchiness was a management objective realized by burning under marginal conditions (late afternoon and early evening) on 26 March 2018. Gray color represents burned area and green color represents unburned patches. Inset photo by Kevin Robertson, taken on 26 March 2018

mechanisms for how local heat transfer relates to withintree physiology emerges as a research and modeling priority (O'Brien et al. 2018), one with a strong nexus to prescribed fire managers.

The significance of expanding our understanding of prescribed fire effects at the appropriate scale extends to wildlife. For example, in longleaf pine (Pinus palustris Mill.) woodlands of the southeastern US, large pines are the nesting substrate for the federally endangered cavitynesting Red-cockaded Woodpecker, Picoides borealis Vieillot (Walters et al. 2002). Frequent fires (more than two fires per decade) are required for the maintenance of Red-cockaded Woodpecker habitat and to minimize cavity tree mortality from higher-intensity fires of longer intervals (Walters et al. 2002). Backing fires are often lit adjacent to individual tree boles such that overall standlevel fire behavior predictions may not correspond to the effects on the cavity trees (Williams et al. 2006). Prescribed fire effects are synergistic with managed ignitions and often highly variable; critical information is lost if predicting fire impacts is approached at coarse scales frequently applied to large wildfires.

Wildfire science has also tended to focus on single-fire events, while prescribed fire science must consider the cumulative and long-term effects of managed fire regimes and fire-vegetation feedbacks that occur at smaller spatial and temporal scales (Freeman et al. 2019). In this light, prescribed fire science is a bridge to fire ecology and ecosystem resilience. Existing fire effects tools (e.g., FOFEM [First Order Fire Effects Model] and its incorporation into other tools [Reinhardt 1997]) tend to be most relevant to conditions following long periods of fire exclusion, including the presence of significant amounts of duff, typical of wildfire scenarios (Pingree and Kobziar 2019). The tools 
needed to guide decision-making to optimize effects of repeated applications of prescribed fire differ greatly from those aimed at minimizing or predicting undesired effects of rare and independent wildfire events $(\mathrm{O}$ Brien et al. 2018). The cumulative effect on vegetation of prescribed fire regimes over the course of many fires has been well demonstrated (Glitzenstein et al. 2012), although little effort yet has been made to predict such effects.

While prediction of fire effects is important to both prescribed fire and wildfire, existing fire effects decisionsupport software systems supported at a national level in the US (e.g., FOFEM, FVS-FFE [Forest Vegetation Simulator-Fire and Fuels Extension; Beukema et al. 2003], IFT-DSS [Interagency Fuel Treatment Decision Support System; Drury et al. 2016]) are most relevant to planning hazardous fuel treatments and post-wildfire response relative to erosion and salvage. They also suffer from inadequate fire effects and fire behavior prediction (see review in Reinhardt and Dickinson 2010). The prototype IFT-DSS had a strong fire effects focus, while the application that is currently operational (http://www. iftdss.firenet.gov) is focused on risk assessment in landscapes where hazardous fuels are a central problem. Development of decision support tools for prescribed fire would necessarily include the non-extreme weather and fuels conditions, links between fire behavior and fire effects at finer scales, and differential seasonal effects (e.g., due to phenology, physiology, or breeding patterns). In addition, for many ecosystems, the frequent and iterative nature of many prescribed burns generates effects that are inherently compounded or influenced by fire-vegetation feedbacks-dynamics not easily captured in existing decision-support tools. For example, three prescribed burns following extended fire exclusion in a single stand have very different consequences than 50 years of burning at a three-year interval, and it is the overall fire regime's effects that require assessment (Freeman et al. 2019). Examples of potential developments include repeated-fires decision-support tools that target how prescribed fire can be used to consume fuels (Gallagher 2017), kill encroaching trees or non-native plants (Engber and Varner 2012), modify wildlife habitat characteristics for species of special concern (Hiers et al. 2016), modify forest structure (Mitchell et al. 2009), release soil nutrients and affect carbon sequestration (Godwin et al. 2017), predict fire emissions (Robertson et al. 2014), and perpetuate particular populations and community assemblages (O'Brien et al. 2016; Dell et al. 2017; Freeman et al. 2019). Although some global vegetation models have advanced capacity to integrate firevegetation-climate dynamics (e.g., Bachelet et al. 2005), they lack flexibility for producing predictions at spatial and temporal scales relevant to prescribed fire decision-making.
The fundamentally experimental nature of prescribed burning offers opportunity for developing mechanistic understanding of fire. Whereas linking pre-fire conditions, fire behavior, and fire effects is difficult and a rarity in wildfire studies (Lydersen et al. 2014; Miesel et al. 2018), the potential to do so exists in almost every prescribed fire (Table 1). Prescribed fire experiments link fire behavior to fire effects in real time, providing the mechanism for addressing questions of fire's role in shaping current and future ecosystems.

\section{Prescribed fire weather}

At first glance, the weather elements important to wildfires and prescribed fires appear quite similar, but their relationships to key indicators, such as area burned, differ greatly (Fig. 5). The basic roles of atmospheric properties such as air temperature, relative humidity, wind, precipitation, and, to a lesser extent, atmospheric stability in the fire environment are well understood. Review studies reveal the importance of vertical interactions between atmospheric conditions and surface fire behavior and weather (Schroeder and Buck 1970; Potter 2012a, 2012b). These reviews culminate with discussions of plume and vortex dynamics (Potter 2012b). A common theme throughout these reviews is how various weather parameters contribute to "blow up fires" or cases of "extreme fire behavior." This focus on the extreme end of the spectrum of fire-atmosphere interactions is understandable as it is critical knowledge for firefighter and community safety; however, such a focus has less utility in a prescribed fire context. More marginal conditions (i.e., higher fine dead fuel moisture) and the generally subdued intensity characteristic of prescribed fires require research into a range of potential fire-atmosphere

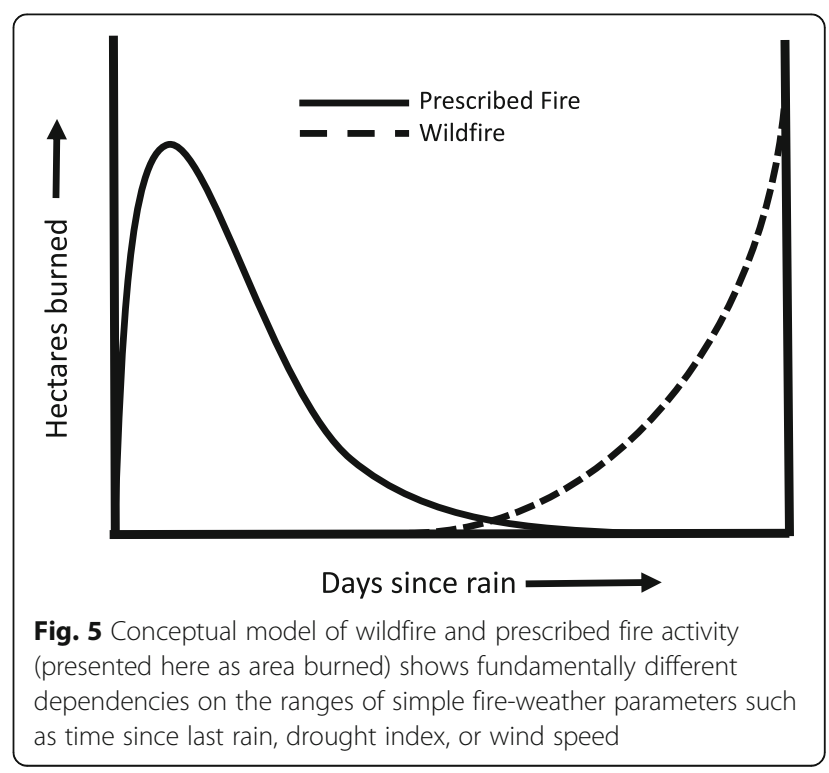


interactions that are masked by the strong buoyant circulations of high-intensity wildfire. As an example, several studies have explored how low-intensity fires influence mean and turbulent flows within a forest canopy, as well as their interactions on smoke transport and dispersion (Kiefer et al. 2013, 2015). These investigations are of clear utility for prescribed fires but will also improve our understanding of wildfires burning under more marginal conditions.

Prescribed fire science will also require a unique and expanded treatment of climate data. For wildfire, the focus from a climate perspective is to identify periods of drought and higher temperatures, since the worst fire seasons tend to occur when one or both factors are higher than normal (Littell et al. 2016). For prescribed fires, the combination of weather conditions required to achieve the desired objective create a much more multifaceted scenario referred to as the "prescription window" (Wade et al. 1989). In prescribed burn planning, weather conditions help define the fire environment used to generate a desired and expected fire behavior, subject to operational constraints. These constraints include resource availability, fuel moisture, and restricted wind directions due to smoke concerns (Fischer 1978; Waldrop and Goodrick 2012; Chiodi et al. 2018). A prescribed fire requires conditions that are dry enough to burn, but not so dry as to elevate fire intensity, cause unwanted damage to the ecosystem, or compromise safety; winds must be sufficient to move the fire and disperse smoke, but not so strong as to cause control problems through elevated intensity or spot-fire ignition. Winds also must be from directions that avoid smoke impacts to sensitive areas. The likelihood of a prescription being met on any given day becomes a problem involving several joint probabilities (e.g., Chiodi et al. 2018), and current tools do not allow for fire planning to adequately vary ignition patterns simultaneously with a range of multiple micrometeorological variables coupled to combustion dynamics. One result is that prescription thresholds for individual parameters are often set conservatively without consideration of the counter-influence of other parameters that may present a broader range of conditions under which prescribed fires can be applied safely and effectively.

Prescribed fire practitioners are considered legally responsible for the smoke their burns produce, which means that precise and accurate predictions of smoke impacts are critical to the successful and safe use of prescribed fire (Charney and Fusina 2006). Prescription windows are significantly influenced by the need to minimize smoke impacts, particularly at night or near smoke-sensitive areas (e.g., Class 1 airsheds in the US [Hyde et al. 2017]). The consideration of smoke for acceptable prescription windows adds meteorological variables such as mixing height and transport winds, or derived indices such as the ventilation index and atmospheric dispersion index (Chiodi et al. 2018). Several tools have been developed to assist land managers in managing smoke; however, these tools currently have large uncertainties, which must be refined if air quality standards become more restrictive (Goodrick et al. 2013). The advancement of smoke research and forecasting systems associated with large-scale, multi-disciplinary prescribed fire experiments, such as FASMEE (Fire and Smoke Model Evaluation Experiment; Liu et al. 2018), is key to supporting the operational needs of prescribed fire managers (Liu et al. 2019).

\section{Conclusions}

The burden of intentional action has always been greater than that of inaction in wildland fire. The focus on wildfires-particularly large-scale fires that challenge firefighting tactics and are extremely costly both financially and in terms of human suffering-has overshadowed the less dramatic but important management needs of prescribed fire. The spatial extent of prescribed fire outpaces wildfire in most years, but the discipline receives a fraction of the research investment or public attention, incurring a significant opportunity loss for wildland fire science. The lack of cross-applicability from wildfirefocused research to prescribed fire science and management has led to both a demand for research and a recognition that tools developed for wildfire management do not support the needs of prescribed fire practitioners. Moreover, climate change is challenging decades of experiential knowledge that has fueled productive prescribed fire management in the absence of adequate supporting science. The research gaps identified in this manuscript represent an important blueprint for addressing the needs of prescribed fire managers worldwide, with important crossover application to managed wildfires (Table 2).

While not explicitly addressed in this manuscript, the social and political dimension in a prescribed fire science agenda cannot be overstated. Arguably, social science does not exhibit the same over-focus on wildfire as detailed above for other disciplines, but any prescribed fire research agenda must include clear and prominent consideration of the full range of ways social science could help improve our understanding of prescribed fire management practices, the burden of intentional action, and how societies can better adapt to fire.

The fundamental differences in fire behavior characteristics between prescribed fires and wildfires exemplify the need for new fire models, smoke dispersion tools, and ecosystem process models capable of capturing the variation and complexity of prescribed fires to meet objectives. Advancements for prescribed fire tools must (1) 
predict the impact of complex ignition patterns; (2) incorporate fire-atmospheric interactions; (3) predict most likely (instead of most extreme) fire behavior that occurs under marginal weather and fuel conditions; (4) accurately account for flanking and backing fire dynamics; and (5) link energy dose to prediction of fire effects. While existing and emerging coupled fire-atmospheric models (Linn et al. 2020) can help predict these phenomena in a research context, readily accessible management tools have yet to be developed. Moreover, tools that advance mechanistic connections of coupled fireatmospheric dynamics to ecological fire effects are years away. In the meantime, research grade models can be used to develop innovative training environments such as virtual reality simulations that game ignition patterns (Furman 2018) and assess fuel treatment effectiveness (Ex et al. 2019). Just as flight simulators are required for pilots, use of such tools for prescribed burn boss training could become a standard supplemental experience to better align fire behavior with prescribed fire planning, implementation, and outcomes.

Prescribed fire science as a disciplinary focus is long overdue, especially as we seek to increase the application of prescribed fire on the landscape (DOI-DOA 2014; Kolden 2019). We argue that this research agenda will be a critical part of managing resilient ecosystems in a rapidly changing world. Investment now into prescribed fire science will help sustain this management tool to meet natural resource management objectives and maintain public safety on both public and private lands. The knowledge and tools developed will not only support prescribed fire management but will likely apply to managed wildfires, improving the integration of ecological outcomes into unplanned ignitions. Prescribed fire is an inherently social-ecological system and is one of the most effective techniques for enabling a future in which people can live sustainably with fire. A focus on the "fires we use" has an immediate impact on the ability to safely and effectively achieve natural resource objectives for societal benefit and ecosystem resilience.

\section{Acknowledgements \\ The workshop that produced this Forum article is the result of shared ideas exchanged over several decades with D. Wade, B. Williams, E. Engber, B. Hornsby, A. Hudak, J. Kreye, S. Larkin, B. Potter, G. Dixon, and others who have struggled with the fundamental differences between science developed for wildfires and the tools and science needed in prescribed fires. Special thanks is given to A. Jonko for assistance with modeling figures.}

\section{Authors' contributions}

All co-authors participated in an experiential fire workshop hosted by the Prescribed Fire Science Consortium at Tall Timbers Research Station, Tallahassee, Florida, USA. Authors J.K. Hiers, J.J. O'Brien, and J.M. Varner led efforts to draft sections from workshop notes and conversations. All other co-authors helped craft intellectual arguments at the workshop, draft individual sections related to their expertise, and comment on and review multiple drafts. All authors read and approved the final manuscript.

\section{Funding}

This work was supported by funds from the National Fire Plan and Tall Timbers Research Station and Land Conservancy. The Southern Fire Exchange, a US Joint Fire Science Program-funded knowledge exchange consortium, helped facilitate this work.

\section{Availability of data and materials}

No new data were presented in this Forum article. All data for figures are available upon request to corresponding author, and are archived at Tall Timbers Research Station, Tallahassee, Florida, USA

Ethics approval and consent to participate

Not applicable.

\section{Consent for publication}

Not applicable.

\section{Competing interests}

The authors declare no conflicts of interest and have undergone required agency review.

\section{Author details}

${ }^{1}$ Tall Timbers Research Station, Tallahassee, Florida 32312, USA. ${ }^{2}$ USDA Forest Service Center for Forest Disturbance Science, Athens, Georgia 30602, USA.

${ }^{3}$ USDA Forest Service Pacific Northwest Research Station, Seattle, Washington 98103, USA. ${ }^{4}$ USDA Forest Service Rocky Mountain Research Station, Missoula, Montana 59808, USA. ${ }^{5}$ USDA Forest Service Northern Research Station, Delaware, Ohio 43015, USA. ${ }^{6}$ USDA Forest Service Northeastern Area State and Private Forestry, Munson, Florida 32570, USA. ${ }^{7}$ USDA Forest Service Northern Research Station, New Lisbon, New Jersey 08064, USA. ${ }^{8}$ Southern Fire Exchange, Tall Timbers Research Station, Tallahassee, Florida 32312, USA. ${ }^{9}$ USDA Forest Service Rocky Mountain Research Station, Moscow, Idaho 83844, USA. ${ }^{10}$ University of Idaho, Department of Natural Resources \& Society, Moscow, Idaho 83844, USA. ${ }^{11}$ Los Alamos National Lab, Los Alamos, New Mexico 87545, USA. ${ }^{12}$ USDA Forest Service Rocky Mountain Research Station, Fort Collins, Colorado 80526, USA. ${ }^{13}$ USDA Forest Service Northern Research Station, Morgantown, West Virginia 26505, USA. ${ }^{14}$ Desert Research Institute, Reno, Nevada 89512, USA. ${ }^{15}$ USDA Forest Service Forest Products Lab, Madison, Wisconsin 53726, USA.

Received: 7 November 2019 Accepted: 21 February 2020

Published online: 19 March 2020

\section{References}

Achtemeier, G.L. 2013. Field validation of a free-agent cellular automata model of fire spread with fire-atmosphere coupling. International Journal of Wildland Fire 22: 148-156 https://doi.org/10.1071/WF11055.

Agee, J.K. 1993. Alternatives for implementing fire policy, Proceedings, Symposium on fire in wilderness and park management, 107-112.

Anderson, H.E. 1982. Aids to determining fuel models for estimating fire behavior Grass, shrub, timber, and slash, photographic examples, danger ratings, USDA Forest Service general technical report INT - Intermountain Forest and Range Experiment Station, 122.

Andrews, P.L. 2007. BehavePlus fire modeling system: past, present, and future. In Proceedings of 7th Symposium on Fire and Forest Meteorology; 23-25 October 2007, Bar Harbor, Maine, 13 p. Boston, MA: American Meteorological Society.

Bachelet, D., J. Lenihan, R. Neilson, R. Drapek, and T. Kittel. 2005. Simulating the response of natural ecosystems and their fire regimes to climatic variability in Alaska. Canadian Journal of Forest Research 35: 2244-2257 https://doi.org/10. 1139/x05-086

Banwell, E.M., J.M. Varner, E.E. Knapp, and R.W. Van Kirk. 2013. Spatial, seasonal, and diel forest floor moisture dynamics in Jeffrey pine-white fir forests of the Lake Tahoe Basin, USA. Forest Ecology and Management 305: 11-20 https://doi.org/10.1016/j.foreco.2013.05.005.

Beukema, S.J., E.D. Reinhardt, J.A. Greenough, D.C. Robinson, and W.A. Kurz. 2003. Fire and fuels extension: model description. In Reinhardt, Elizabeth; Crookston, Nicholas L. (Technical Editors). The Fire and Fuels Extension to the Forest Vegetation Simulator. Gen. Tech. Rep. RMRS-GTR-116, 11-60., 116. Ogden, UT: US Department of Agriculture, Forest Service, Rocky Mountain Research Station https://doi.org/10.2737/RMRS-GTR-116. 
Boer, M.M., R.J. Sadler, R.S. Wittkuhn, L. McCaw, and P.F. Grierson. 2009. Long-term impacts of prescribed burning on regional extent and incidence of wildfiresevidence from 50 years of active fire management in SW Australian forests. Forest Ecology and Management 259: 132-142 https://doi.org/10.1016/j.foreco. 2009.10.005.

Bragg, T.B., and L.C. Hulbert. 1976. Woody plant invasion of unburned Kansas bluestem prairie. Rangeland Ecology \& Management/Journal of Range Management Archives 29: 19-24 https://doi.org/10.2307/3897682.

Brown, J.K. 1974. Handbook for inventorying downed woody material, 24. Ogden, Utah: USDA Forest Service, Intermountain Research Station.

Charney, J.J., and L.A. Fusina. 2006. Employing numerical weather models to enhance fire weather and fire behavior predictions. In Andrews, Patricia L; Butler, Bret W., comps. 2006. Fuels Management-How to Measure Success: Conference Proceedings. 28-30 March 2006; Portland, OR. Proceedings RMRSP-41, 769-785. Fort Collins, CO: US Department of Agriculture, Forest Service, Rocky Mountain Research Station.

Chiodi, A., N. Larkin, and J.M. Varner. 2018. An analysis of Southeastern US prescribed burn weather windows: seasonal variability and El Niño associations. International Journal of Wildland Fire 27: 176-189 https://doi.org/10.1071/WF17132.

Chuvieco, E., L. Giglio, and C. Justice. 2008. Global characterization of fire activity: toward defining fire regimes from Earth observation data. Global Change Biology 14: 1488-1502 https://doi.org/10.1111/j.1365-2486.2008.01585.x.

Clements, C.B., N.P. Lareau, D. Seto, J. Contezac, B. Davis, C. Teske, T.J. Zajkowski, A.T. Hudak, B.C. Bright, and M.B. Dickinson. 2016. Fire weather conditions and fire-atmosphere interactions observed during low-intensity prescribed firesRxCADRE 2012. International Journal of Wildland Fire 25: 90-101 https://doi. org/10.1071/WF14173.

Coen, J. 2013. Modeling wildland fires: A description of the Coupled Atmosphere-Wildland Fire Environment model (CAWFE)

Coen, J.L., M. Cameron, J. Michalakes, E.G. Patton, P.J. Riggan, and K.M. Yedinak. 2013. WRF-Fire: coupled weather-wildland fire modeling with the weather research and forecasting model. Journal of Applied Meteorology and Climatology 52: 16-38 https://doi.org/10.1175/JAMC-D-12-023.1.

Covington, W.W., and M.M. Moore. 1994. Southwestern ponderosa forest structure: changes since Euro-American settlement. Journal of Forestry 92: 39-47.

Cruz, M.G., J.S. Gould, M.E. Alexander, A.L. Sullivan, W.L. McCaw, and S. Matthews. 2015. Empirical-based models for predicting head-fire rate of spread in Australian fuel types. Australian Forestry 78: 118-158 https://doi.org/10.1080/ 00049158.2015 .1055063

Deeming I, Lancaster I, Fosberg M, Furman R, Schroeder M. 1972. HI. The National Fire-Danger Rating System. USDA Forest Service Research Paper RM-84 February. https://doi.org/10.5962/bhl.title.98933

Dell, J.E., L.A. Richards, J.J. O'Brien, E.L. Loudermilk, A.T. Hudak, S.M. Pokswinski, B. C. Bright, J.K. Hiers, B.W. Williams, and L.A. Dyer. 2017. Overstory-derived surface fuels mediate plant species diversity in frequently burned longleaf pine forests. Ecosphere 8 https://doi.org/10.1002/ecs2.1964.

Dickinson, M.B., and K.C. Ryan. 2010. Introduction: strengthening the foundation of wildland fire effects prediction for research and management. Fire Ecology 6: 1-12 https://doi.org/10.4996/fireecology.0601001.

DOI-DOA U. 2014. The National Strategy: The Final Phase in the Development of the National Cohesive Wildland Fire Management Strategy, Washington, DC, April 2014

Drury, S.A., H.M. Rauscher, E.M. Banwell, S. Huang, and T.L. Lavezzo. 2016. The interagency fuels treatment decision support system: functionality for fuels treatment planning. Fire Ecology 12 (1): 103-123 https://doi.org/10.4996/ fireecology.1201103.

Engber, E., and J. Varner. 2012. Reversing conifer encroachment with prescribed fire: shifting mortality models toward restoration targets. Restoration Ecology 20: 665-668 https://doi.org/10.1111/j.1526-100X.2012.00900.x.

Ex, S.A., J.P. Ziegler, W.T. Tinkham, and C.M. Hoffman. 2019. Long-Term Impacts of Fuel Treatment Placement with Respect to Forest Cover Type on Potential Fire Behavior across a Mountainous Landscape. Forests 10: 438 https://doi. org/10.3390/f10050438.

Fernandes, P.M., and H.S. Botelho. 2003. A review of prescribed burning effectiveness in fire hazard reduction. International Journal of Wildland Fire 12: 117-128 https://doi.org/10.1071/WF02042

Finney, M.A. 1998. FARSITE: Fire Area Simulator-model development and evaluation. Res. Pap. RMRS-RP-4, Revised 2004, 4. Ogden, UT: US Department of Agriculture, Forest Service, Rocky Mountain Research Station. 47 https:// doi.org/10.2737/RMRS-RP-4.

Finney, M.A. 2004. Landscape fire simulation and fuel treatment optimization. Methods for integrating modeling of landscape change: Interior Northwest Landscape Analysis
System. Gen. Tech. Rep. PNW-GTR-610, 117-131. Portland, OR: US Department of Agriculture, Forest Service, Pacific Northwest Research Station. 2004 Sep.

Finney, M.A., J.D. Cohen, J.M. Forthofer, S.S. McAllister, M.J. Gollner, D.J. Gorham, K. Saito, N.K. Akafuah, B.A. Adam, and J.D. English. 2015. Role of buoyant flame dynamics in wildfire spread. Proceedings of the National Academy of Sciences 112: 9833-9838 https://doi.org/10.1073/pnas.1504498112.

Fischer, W.C. 1978. Planning and evaluating prescribed fires--a standard procedure. Gen. Tech. Rep. INT-GTR-43, 19. Ogden, UT: US Department of Agriculture, Forest Service, Intermountain Forest and Range Experiment Station.

Freeman, J.E., L.N. Kobziar, E.H. Leone, and K. Williges. 2019. Drivers of plant functional group richness and beta diversity in fire-dependent pine savannas. Diversity and Distributions https://doi.org/10.1111/ddi.12926.

Furman, J. 2018. Next Generation Fire Modeling for Advanced Wildland Fire Training. Fire Management Today 78: 48-53.

Gallagher MR. 2017. Monitoring fire effects in the New Jersey Pine Barrens with burn severity indices. Rutgers University-School of Graduate Studies.

Gisborne, H. 1942. Mileposts of progress in fire control and fire research. Journal of Forestry 40: 597-608.

Glitzenstein, J.S., D.R. Streng, R.E. Masters, K.M. Robertson, and S.M. Hermann. 2012. Fire-frequency effects on vegetation in north Florida pinelands: Another look at the long-term Stoddard Fire Research Plots at Tall Timbers Research Station. Forest Ecology and Management 264: 197-209 https://doi. org/10.1016/j.foreco.2011.10.014.

Godwin, D., L. Kobziar, and K. Robertson. 2017. Effects of fire frequency and soil temperature on soil $\mathrm{CO} 2$ efflux rates in old-field pine-grassland forests. Forests 8: 274 https://doi.org/10.3390/f8080274.

Gomes Da Cruz, M., L. McCaw, W.R. Anderson, and J. Gould. 2013. Fire behaviour modelling in semi-arid mallee-heath shrublands of southern Australia. Environmental Modelling \& Software 40: 21-34 https://doi.org/10.1016/j. envsoft.2012.07.003.

Goodrick, S.L., G.L. Achtemeier, N.K. Larkin, Y. Liu, and T.M. Strand. 2013. Modelling smoke transport from wildland fires: a review. International Journal of Wildland Fire 22: 83-94 https://doi.org/10.1071/WF11116.

Hawley, C.M., E.L. Loudermilk, E.M. Rowell, and S. Pokswinski. 2018. A novel approach to fuel biomass sampling for 3D fuel characterization. Methods $X$ 5: 1597-1604 https://doi.org/10.1016/j.mex.2018.11.006.

Hiers, J.K., S.T. Jackson, R.J. Hobbs, E.S. Bernhardt, and L.E. Valentine. 2016. The Precision Problem in Conservation and Restoration. Trends in Ecology \& Evolution 31: 820-830 https://doi.org/10.1016/j.tree.2016.08.001.

Hiers, J.K., J.J. O'Brien, R.J. Mitchell, J.M. Grego, and E.L. Loudermilk. 2009. The wildland fuel cell concept: an approach to characterize fine-scale variation in fuels and fire in frequently burned longleaf pine forests. International Journal of Wildland Fire 18: 315-325 https://doi.org/10.1071/WF08084.

Hiers, J.K., C.L. Stauhammer, J.J. O'Brien, H.L. Gholz, T.A. Martin, J. Hom, and G. Starr. 2019. Fine dead fuel moisture shows complex lagged responses to environmental conditions in a saw palmetto (Serenoa repens) flatwoods. Agricultural and Forest Meteorology 266: 20-28 https://doi.org/10.1016/j. agrformet.2018.11.038.

Hurteau, M.D., G.W. Koch, and B.A. Hungate. 2008. Carbon protection and fire risk reduction: toward a full accounting of forest carbon offsets. Frontiers in Ecology and the Environment 6: 493-498 https://doi.org/10.1890/070187.

Hyde, J.C., A.M. Smith, R.D. Ottmar, E.C. Alvarado, and P. Morgan. 2011. The combustion of sound and rotten coarse woody debris: a review. International Journal of Wildland Fire 20: 163-174 https://doi.org/10.1071/WF09113.

Hyde, J.C., K.M. Yedinak, A.F. Talhelm, A.M. Smith, D.M. Bowman, F.H. Johnston, P. Lahm, M. Fitch, and W.T. Tinkham. 2017. Air quality policy and fire management responses addressing smoke from wildland fires in the United States and Australia. International Journal of Wildland Fire 26: 347363 https://doi.org/10.1071/WF16154.

Johnson, E., and K. Miyanishi. 2001. Strengthening fire ecology's roots. In Forest Fires: Behavior and Ecological Effects, ed. E. Johnson and K. Miyanishi, 1-9. San Diego, CA: Forest Fires: Behavior and Ecological Effects https://doi.org/10. 1016/B978-012386660-8/50003-9.

Jolly, W., and D. Johnson. 2018. Pyro-ecophysiology: shifting the paradigm of live wildland fuel research. Fire 1: 8 https://doi.org/10.3390/fire1010008.

Jolly, W.M., A.M. Hadlow, and K. Huguet. 2014. De-coupling seasonal changes in water content and dry matter to predict live conifer foliar moisture content. International Journal of Wildland Fire 23: 480-489 https://doi.org/10.1071/WF13127.

Jones, G.M., R. Gutiérrez, D.J. Tempel, S.A. Whitmore, W.J. Berigan, and M.Z. Peery. 2016. Megafires: an emerging threat to old-forest species. Frontiers in Ecology and the Environment 14: 300-306 https://doi.org/10.1002/fee.1298. 
Kaufmann, M.R., and A. Shlisky. 2005. Good fire, bad fire: how to think about forest land management and ecological processes, 16. Fort Collins, CO: US Department of Agriculture, Forest Service, Rocky Mountain Research Station.

Kiefer, M., S. Zhong, W. Heilman, J. Charney, and X. Bian. 2013. Evaluation of an ARPS-based canopy flow modeling system for use in future operational smoke prediction efforts. Journal of Geophysical Research: Atmospheres 118: 6175-6188 https://doi.org/10.1002/jgrd.50491.

Kiefer, M.T., W.E. Heilman, S. Zhong, J.J. Charney, and X. Bian. 2015. Mean and turbulent flow downstream of a low-intensity fire: Influence of canopy and background atmospheric conditions. Journal of Applied Meteorology and Climatology 54: $42-57$ https://doi.org/10.1175/JAMC-D-14-0058.1.

Kolden, C.A. 2019. We're Not Doing Enough Prescribed Fire in the Western United States to Mitigate Wildfire Risk. Fire 2: 30 https://doi.org/10.3390/fire2020030.

Kreye, J.K., J.K. Hiers, J.M. Varner, B. Hornsby, S. Drukker, and J.J. O'Brien. 2018. Effects of solar heating on the moisture dynamics of forest floor litter in humid environments: composition, structure, and position matter. Canadian Journal of Forest Research 48: 1331-1342 https://doi.org/10.1139/cjfr-2018-0147.

Linn, R., J. Canfield, P. Cunningham, C. Edminster, J.-L. Dupuy, and F. Pimont. 2012. Using periodic line fires to gain a new perspective on multidimensional aspects of forward fire spread. Agricultural and Forest Meteorology 157: 60-76 https://doi.org/10.1016/j.agrformet.2012.01.014.

Linn, R., J. Reisner, J.J. Colman, and J. Winterkamp. 2002. Studying wildfire behavior using FIRETEC. International Journal of Wildland Fire 11: 233-246 https://doi.org/10.1071/WF02007.

Linn, R.R., S. L., Goodrick, S. Brambilla, M.J. Brown, R.S. Middleton, J.J. O'Brien, and J.K. Hiers. 2020. QUIC-fire: A fast-running simulation tool for prescribed fire planning. Environmental Modelling \& Software, 125, 104616.

Linn, R.R., C.H. Sieg, C.M. Hoffman, J.L. Winterkamp, and J.D. McMillin. 2013. Modeling wind fields and fire propagation following bark beetle outbreaks in spatially-heterogeneous pinyon-juniper woodland fuel complexes. Agricultural and Forest Meteorology 173: 139-153 https://doi.org/10.1016/j. agrformet.2012.11.007.

Littell, J.S., D.L. Peterson, K.L. Riley, Y. Liu, and C.H. Luce. 2016. A review of the relationships between drought and forest fire in the United States. Global Change Biology 22: 2353-2369 https://doi.org/10.1111/gcb.13275.

Liu, Y., S. Goodrick, and G. Achtemeier. 2018. The weather conditions for desired smoke plumes at a FASMEE burn site. Atmosphere 9 (7): 259 https://doi.org/ 10.3390/atmos9070259.

Liu, Y., A. Kochanski, K. Baker, W. Mell, R. Linn, R. Paugam, J. Mandel, A. Fournier, M.A. Jenkins, and S. Goodrick. 2019. Fire behavior and smoke modeling: Model improvement and measurement needs for next-generation operational smoke prediction systems. International Journal of Wildland Fire https://doi.org/10.1071/WF18204.

Loudermilk, E.L., J.K. Hiers, and J.J. O'Brien. 2018. The role of fuels for understanding fire behavior and fire effects. In Ecological restoration and management of longleaf pine forests., ed. L. Katherine Kirkman and Steven B. Jack, 107-122. CRC Press, Taylor \& Francis Group (pp. 107-122). Boca Raton (Florida).

Loudermilk, E.L., J.K. Hiers, J.J. O'Brien, R.J. Mitchell, A. Singhania, J.C. Fernandez, W. P. Cropper, and K.C. Slatton. 2009. Ground-based LIDAR: a novel approach to quantify fine-scale fuelbed characteristics. International Journal of Wildland Fire 18: 676-685 https://doi.org/10.1071/WF07138.

Lydersen, J.M., M.P. North, and B.M. Collins. 2014. Severity of an uncharacteristically large wildfire, the Rim Fire, in forests with relatively restored frequent fire regimes. Forest Ecology and Management 328: 326-334 https://doi.org/10.1016/j.foreco.2014.06.005.

Maxwell, W.G., and F.R. Ward. 1980. Photo series for quantifying natural forest residues in common vegetation types of the Pacific Northwest. Gen. Tech. Rep. PNW-GTR-105. Portland, OR: US Department of Agriculture, Forest Service, Pacific Northwest Forest and Range Experiment Station 105 https://doi.org/ 10.2737/PNW-GTR-105.

McCaw, W.L. 2013. Managing forest fuels using prescribed fire-a perspective from southern Australia. Forest Ecology and Management 294: 217-224 https://doi. org/10.1016/j.foreco.2012.09.012.

McCullers, S. 2013. A dangerous servant and a fearful master: why Florida's prescribed fire statute should be amended. Florida Law Review 65: 587.

Meddens, A.J., C.A. Kolden, J.A. Lutz, A.M. Smith, C.A. Cansler, J.T. Abatzoglou, G.W. Meigs, W.M. Downing, and M.A. Krawchuk. 2018. Fire Refugia: What Are They, and Why Do They Matter for Global Change? BioScience 68: 944-954 https:// doi.org/10.1093/biosci/biy103.

Mell, W., J. Charney, M.A. Jenkins, P. Cheney, and J. Gould. 2013. Numerical simulations of grassland fire behavior from the LANL-FIRETEC and NIST-WFDS models. In Remote Sensing and Modeling Applications to Wildland Fires Sensing and Modeling Applications to Wildland Fires (pp. 209-225). Springer, Berlin, Heidelberg.

Melvin M. 2018. 2018 National prescribed fire use survey report. Technical Report 03-18 Coalition of Prescribed Fire Councils, Inc.

Miesel, J., A. Reiner, C. Ewell, B. Maestrini, and M. Dickinson. 2018. Quantifying changes in total and pyrogenic carbon stocks across fire severity gradients using active wildfire incidents. Frontiers in Earth Science 6: 41 https://doi.org/ 10.3389/feart.2018.00041.

Mitchell, R.J., J.K. Hiers, J. O'Brien, and G. Starr. 2009. Ecological Forestry in the Southeast: Understanding the Ecology of Fuels. Journal of Forestry 107: 391-397.

Molina-Terrén, D., A. Cardil, and L. Kobziar. 2016. Practitioner perceptions of wildland fire management across South Europe and Latin America. Forests 7: 184 https://doi.org/10.3390/f7090184.

Nelson, R.M., Jr. 2001. Water relations of forest fuels. In Forest fires (79-149). Academic Press, Cambridge.

O'Brien, J., J. Hiers, J. Varner, C. Hoffman, M. Dickinson, S. Michaletz, E. Loudermilk, and B. Butler. 2018. Advances in mechanistic approaches to quantifying biophysical fire effects. Current Forestry Reports 4: 161-177 https://doi.org/10. 1007/s40725-018-0082-7.

O'Brien, J.J., E.L. Loudermilk, J.K. Hiers, B. Hornsby, S. Pokswinski, A.T. Hudak, D. Strother, E. Rowell, and B. Bright. 2016. Canopy derived fuels drive patterns of in-fire energy release and understory plant mortality in a longleaf pine (Pinus palustris) sandhill in Northwest FL, USA. Canadian Journal of Remote Sensing 42: 489-500 https://doi.org/10.1080/07038992.2016.1199271.

Ottmar, R. D., Hiers, J. K., Butler, B. W., Clements, C. B., Dickinson, M. B., Hudak, A. T., O'Brien, J. J., Potter, B. E., Rowell, E. M., Strand, T. M., and Zajkowski, T. J. 2016. Measurements, datasets and preliminary results from the RxCADRE project2008, 2011 and 2012. International Journal of Wildland Fire 25(1): 1-9.

Parsons, R.A., R.R. Linn, F. Pimont, C. Hoffman, J. Sauer, J. Winterkamp, C.H. Sieg, and W.M. Jolly. 2017. Numerical investigation of aggregated fuel spatial pattern impacts on fire behavior. Land 6: 43 https://doi.org/10.3390/ land6020043.

Parsons, R.A., W.E. Mell, and P. McCauley. 2011. Linking 3D spatial models of fuels and fire: Effects of spatial heterogeneity on fire behavior. Ecological Modelling 222: 679-691 https://doi.org/10.1016/j.ecolmodel.2010.10.023.

Pimont, F., J.-L. Dupuy, R.R. Linn, and S. Dupont. 2009. Validation of FIRETEC windflows over a canopy and a fuel-break. International Journal of Wildland Fire 18: 775-790 https://doi.org/10.1071/WF07130.

Pingree, M.R., and L.N. Kobziar. 2019. The myth of the biological threshold: A review of biological responses to soil heating associated with wildland fire. Forest Ecology and Management 432: 1022-1029 https://doi.org/10.1016/j. foreco.2018.10.032.

Potter, B.E. 2012a. Atmospheric interactions with wildland fire behaviour-I. Basic surface interactions, vertical profiles and synoptic structures. International Journal of Wildland Fire 21: 779-801 https://doi.org/10.1071/WF11128.

Potter, B.E. 2012b. Atmospheric interactions with wildland fire behaviour-II. Plume and vortex dynamics. International Journal of Wildland Fire 21: 802-817 https://doi.org/10.1071/WF11129.

Reeves, M.C., K.C. Ryan, M.G. Rollins, and T.G. Thompson. 2009. Spatial fuel data products of the LANDFIRE project. International Journal of Wildland Fire 18: 250-267 https://doi.org/10.1071/WF08086.

Reid, A.M., K.M. Robertson, and T.L. Hmielowski. 2012. Predicting litter and live herb fuel consumption during prescribed fires in native and old-field upland pine communities of the southeastern United States. Canadian Journal of Forest Research-Revue Canadienne De Recherche Forestiere 42: 1611-1622 https://doi.org/10.1139/×2012-096.

Reinhardt, E. D. (1997). First order fire effects model: FOFEM 4.0, user's guide (No. 344-345). Intermountain Forest and Range Experiment Station, Forest Service, US Department of Agriculture. https://doi.org/10.2737/INT-GTR-344

Reinhardt, E.D., and M.B. Dickinson. 2010. First-order fire effects models for land management: overview and issues. Fire Ecology 6: $131 \mathrm{https} / / / \mathrm{doi} .0 \mathrm{rg} / 10$. 4996/fireecology.0601131.

Robertson, K.M., Y.P. Hsieh, and G.C. Bugna. 2014. Fire environment effects on particulate matter emission factors in southeastern US pine-grasslands. Atmospheric Environment 99: 104-111 https://doi.org/10.1016/j.atmosenv.2014. 09.058.

Rollins, M.G. 2009. LANDFIRE: a nationally consistent vegetation, wildland fire, and fuel assessment. International Journal of Wildland Fire 18: 235-249 https://doi. org/10.1071/WF08088. 
Rothermel, R.C. 1972. A mathematical model for predicting fire spread in wildland fuels, US Department of Agriculture, Forest Service, Intermountain Forest and Range Experiment Station. General Technical Report no. INT-115, 40.

Rothermel RC. 1983. How to predict the spread and intensity of forest and range fires. The Bark Beetles, Fuels, and Fire Bibliography. US Department of Agriculture, Forest Service, Intermountain Forest and Range Experiment Station. General Technical Report no. INT-143. https://doi.org/10.2737/INT-GTR-143

Rowell, E., E.L. Loudermilk, C. Seielstad, and J.J. O'Brien. 2016. Using simulated 3D surface fuelbeds and terrestrial laser scan data to develop inputs to fire behavior models. Canadian Journal of Remote Sensing 42: $443-459$ https://doi. org/10.1080/07038992.2016.1220827.

Ryan, K.C., E.E. Knapp, and J.M. Varner. 2013. Prescribed fire in North American forests and woodlands: history, current practice, and challenges. Frontiers in Ecology and the Environment 11: e15-e24 https://doi.org/10.1890/120329.

Sandberg, D.V., R.D. Ottmar, and G.H. Cushon. 2001. Characterizing fuels in the 21st century. International Journal of Wildland Fire 10: 381-387 https://doi.org/ 10.1071/WF01036.

Schroeder, M.J., and C.C. Buck. 1970. Fire weather: a guide for application of meteorological information to forest fire control operations, The Bark Beetles, Fuels, and Fire Bibliography, 14.

Scott, A.C., D.M. Bowman, W.J. Bond, S.J. Pyne, and M.E. Alexander. 2013. Fire on earth: an introduction: John Wiley \& Sons.

Skowronski, N.S., K.L. Clark, M. Duveneck, and J. Hom. 2011. Three-dimensional canopy fuel loading predicted using upward and downward sensing LiDAR systems. Remote Sensing of Environment 115: $703-714$ https://doi.org/10.1016/ j.rse.2010.10.012.

Smith, A.M., A.F. Talhelm, D.M. Johnson, A.M. Sparks, C.A. Kolden, K.M. Yedinak, K. G. Apostol, W.T. Tinkham, J.T. Abatzoglou, and J.A. Lutz. 2017. Effects of fire radiative energy density dose on Pinus contorta and Larix occidentalis seedling physiology and mortality. International Journal of Wildland Fire 26: 82-94 https://doi.org/10.1071/WF16077.

Stephens, S.L., N. Burrows, A. Buyantuyev, R.W. Gray, R.E. Keane, R. Kubian, S. Liu, F. Seijo, L. Shu, and K.G. Tolhurst. 2014. Temperate and boreal forest megafires: characteristics and challenges. Frontiers in Ecology and the Environment 12: 115-122 https://doi.org/10.1890/120332.

Stephens, S.L., and L.W. Ruth. 2005. Federal forest-fire policy in the United States. Ecological Applications 15: 532-542 https://doi.org/10.1890/04-0545.

Stocks, B. J., Alexander, M. E., and Lanoville, R. A. 2004. Overview of the international crown fire modelling experiment (ICFME). Canadian Journal of Forest Research, 34(8), 1543-1547.

Sullivan, A.L. 2009a. Wildland surface fire spread modelling, 1990-2007. 1: Physical and quasi-physical models. International Journal of Wildland Fire 18: 349-368 https://doi.org/10.1071/WF06143.

Sullivan, A.L. 2009b. Wildland surface fire spread modelling, 1990-2007. 2: Empirical and quasi-empirical models. International Journal of Wildland Fire 18: 369-386 https://doi.org/10.1071/WF06142.

Tanskanen, H., A. Granström, A. Venäläinen, and P. Puttonen. 2006. Moisture dynamics of moss-dominated surface fuel in relation to the structure of Picea abies and Pinus sylvestris stands. Forest Ecology and Management 226: 189-198 https://doi.org/10.1016/j.foreco.2006.01.048.

Varner, J.M., J.K. Hiers, R.D. Ottmar, D.R. Gordon, F.E. Putz, and D.D. Wade. 2007. Overstory tree mortality resulting from reintroducing fire to long-unburned longleaf pine forests: The importance of duff moisture. Canadian Journal of Forest Research 37: 1349-1358 https://doi.org/10.1139/X06-315.

Wade, D.D., J.D. Lunsford, M.J. Dixon, and H.E. Mobley. 1989. A Guide for Prescribed Fire in Southern Forests, 56. Atlanta, GA: US Department of Agriculture, Forest Service.

Waldrop, T.A., and S.L. Goodrick. 2012. Introduction to prescribed fires in Southern ecosystems. Science Update SRS-054. Asheville, NC: US Department of Agriculture, Forest Service, Southern Research Station. General Technical Report 54: 1-80.

Walters, J.R., S.J. Daniels, J.H. Carter III, and P.D. Doerr. 2002. Defining quality of redcockaded woodpecker foraging habitat based on habitat use and fitness. The Journal of Wildlife Management: 1064-1082 https://doi.org/10.2307/3802938.

Whelan, R.J. 1995. The Ecology of Fire, 346. Cambridge, UK: Cambridge University Press.

Wiesner, S., C.L. Staudhammer, C.L. Javaheri, J.K. Hiers, L.R. Boring, R.J. Mitchell, and G. Starr. 2019. The role of understory phenology and productivity in the carbon dynamics of longleaf pine savannas. Ecosphere 10: e02675 https://doi. org/10.1002/ecs2.2675.

Williams, B.W., E.B. Moser, J.K. Hiers, K. Gault, and D.K. Thurber. 2006. Protecting red-cockaded woodpecker cavity trees predisposed to fire-induced mortality.
The Journal of Wildlife Management 70: 702-707 https://doi.org/10.2193/0022541X(2006)70[702:PRWCTP]2.0.CO;2.

Yedinak, K., E. Strand, J. Hiers, and J. Varner. 2018. Embracing complexity to advance the science of wildland fire behavior. Fire 1: 20 https://doi.org/10. 3390/fire1020020.

Yoder, J. 2008. Liability, regulation, and endogenous risk: the incidence and severity of escaped prescribed fires in the United States. The Journal of Law and Economics 51: 297-325 https://doi.org/10.1086/589661.

Zhou, X., S. Mahalingam, and D. Weise. 2005. Modeling of marginal burning state of fire spread in live chaparral shrub fuel bed. Combustion and Flame 143: 183-198 https://doi.org/10.1016/j.combustflame.2005.05.013.

\section{Publisher's Note}

Springer Nature remains neutral with regard to jurisdictional claims in published maps and institutional affiliations.

\section{Submit your manuscript to a SpringerOpen ${ }^{\circ}$ journal and benefit from:}

- Convenient online submission

- Rigorous peer review

- Open access: articles freely available online

- High visibility within the field

- Retaining the copyright to your article

Submit your next manuscript at $\boldsymbol{\nabla}$ springeropen.com 